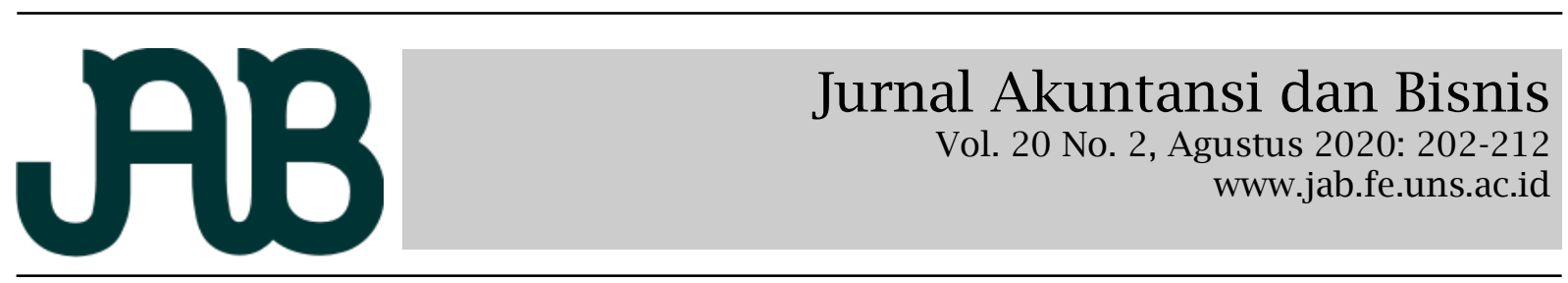

\title{
SHOULD COMPANIES ENGAGE IN CSR? EVIDENCE FROM CSR IMPACT ON COST OF
} CAPITAL IN TOP ASEAN COMPANIES

\author{
DIAH AGUSTINA PRIHASTIWI (diahprihastiwi@untidar.ac.id) \\ ARI NURUL FATIMAH
}

Accountung Study Program, Economic Faculty, Universitas Tidar, Indonesia

\begin{abstract}
A B S T R A C T
The growing concern of business's effect on social and the environment has been unprecedented. Companies must do their part as corporate citizens. Despite the rising public demand, many companies still hesitate in doing so. The purpose of this study is to give evidence that engaging in CSR activities can have an impact on the cost of capital, represented by the cost of equity (COE) and the cost of debt (COD). Using 200 companies in ASEAN during the period 2017-2019 as samples, we estimate the relationship between a company's sustainability reporting and its COE and COD. COE is measured based on an excess of return and COD is measured by interest rate. Utilizing multiple regression analysis, the findings showed that disclosure of CSR activities can help reduce COE. However, the analysis result provides no evidence regarding the relationship between sustainability reporting and COD. This study provides evidence that engaging in CSR can give benefit to companies through the reduction of COE.

Keywords: sustainability reporting, CSR disclosure, cost of capital, cost of equity, cost of debt, stakeholder theory.

Perhatian masyarakat terhadap dampak dari operasi bisnis terhadap sosial dan lingkungan belum pernah terjadi sebelumnya. Perusahaan harus melakukan perannya sebagai bagian dari masyarakat corporate citizens. Meski permintaan masyarakat meningkat, banyak perusahaan masih ragu untuk melakukannya. Tujuan dari penelitian ini adalah untuk memberikan bukti bahwa melakukan kegiatan CSR dapat berdampak pada biaya modal (cost of capital), yang diwakili oleh biaya ekuitas (cost of equity/COE) dan biaya utang (cost of debt/COD). Dengan menggunakan 200 perusahaan di ASEAN selama periode 2017-2019 sebagai sampel, kami meneliti hubungan antara pelaporan berkelanjutan (sustainability reporting) perusahaan dengan COE dan COD. COE diukur berdasarkan kelebihan return dan COD diukur menggunakan suku bunga. Dengan menggunakan analisis regresi berganda, hasil penelitian menunjukkan bahwa pengungkapan kegiatan CSR dapat membantu menurunkan COE. Akan tetapi, hasil analisis tidak memberikan dukungan hubungan yang signifikan antara sustainability reporting dan COD. Studi ini memberikan bukti bahwa melakukan CSR dapat memberikan manfaat bagi perusahaan melalui pengurangan COE.

Kata kunci: sustainability reporting, pengungkapan CSR, cost of capital, cost of equity, cost of debt, teori pemangku kepentingan.
\end{abstract}

\section{INTRODUCTION}

The development of financial markets has made corporate social responsibility (CSR) increasingly important to companies. Apart from having to focus on increasing profits, a company must also maximize its efforts to achieve good governance. National and multinational companies must run their business by paying attention to environmental, social, and good governance factors, as well as relationships with various stakeholders in every decision-making and business processes (Oikonomou, Brooks \& Pavelin, 2014).

Nowadays, managers have realized that using sustainability reporting can give rise to long-term performance and value creation of companies (De Villiers \& Maroun, 2018; Safitri, 2013). Consequently, companies have increased significantly the quantity and quality of their CSR disclosure in the hope to get more acknowledgement from society. Ultimately, they expect more value creation for the companies in the fu- 
ture (Ali, Lodhia \& Narayan, 2020). However, most of the researches in sustainability reporting consider CSR as a potential for value creation by connecting CSR performance with firm financial performance (Ainy \& Barokah (2019); Anindita (2014); Haq (2020); Kusuma \& Aryani (2020); and Wimatsari (2014)). Whereas, CSR can be considered as a corporate governance mechanism to mitigate risks, especially risks related to the capital market (Ahmed, Eliwa \& Power, 2019; Magnanelli \& Izzo, 2017; Oikonomou et al., 2014). Therefore, in this study, we try to fill this gap by providing further evidence of the role of CSR disclosure in reducing COC.

Various studies have shown that companies consistently disclose complete, timely, and informative financial and nonfinancial information can take benefit in financial markets, for example, lower cost of capital (COC) and higher access to capital markets (García-Sánchez, Hussain, Martínez-Ferrero \& Ruiz-Barbadillo, 2019). Results of studies on the impact of nonfinancial information disclosure on COC tend to produce various conclusions, namely the higher the level of financial information disclosure can reduce, increase, or have no effect on the cost of capital (Bhuiyan \& Nguyen, 2019). However, most of the researchers seem to agree that nonfinancial information disclosure can affect risk assessment differently. Although, research on the association of non-financial information disclosure to the cost of capital still yields mixed conclusions because of content-specific information (Yeh, Lin, Wang \& Wu, 2019). One of the non-financial information in the spotlight at this time is CSR information.

Furthermore, sustainability reporting implementation continues to increase, especially for companies in ASEAN. This increase is due to the growing development of guidelines and demands globally as well as the entry of multinational corporations (MNCs) in ASEAN. In addition, international organizations take the initiative to create added value for companies that follow these directions. Companies must sustainably formulate their business strategies and increase the transparency of their disclo- sures. Stakeholder expectations are not only for profit creation but companies' commitment and initiatives to sustainable development (Loh \& Thomas, 2018). However, various studies on CSR in ASEAN show that the results have not yet reached the same conclusion. Hashim, Ries \& Huai (2019) found that CSR does not influence a company's financial performance in ASEAN telecommunications companies. In addition, research conducted by Pusparida \& Harto (2016) also found that CSR by banks in ASEAN has a negative effect on COC. ASEAN as a research object provides a unique characteristic, as it has different circumstances than western companies, this question remains unresolved by researchers.

This research will contribute by adding insight into the field of CSR disclosure and its impact on $\mathrm{COC}$, which currently provides mixed results. Research on CSR in ASEAN is currently still limited to certain industries Hashim et al. (2019) and Pusparida \& Harto (2016). Therefore, this study uses 200 samples of companies in ASEAN. This will be this research's foremost academic contribution. It will provide evidence of the relationship between CSR and $\mathrm{COC}$ in the ASEAN region as a whole, where similar research is still limited. Specifically, this study will contribute by providing an overview of the current conditions of CSR implementation in ASEAN as a whole and its impact on COC. The expected impact is companies are convinced that engaging in environmental and community development will provide financial benefits. Thus, companies will increase their role as good corporate citizens. The purpose of this study is to show the impact of CSR performance disclosure with the cost of equity (COE) and cost of debt (COD) based on stakeholder theory. The financial market (equity) which is still developing in the ASEAN region causes debt as one of the main sources of funding for companies, resulting in agency problems between shareholders and debtors (Hashim et al., 2019). This motivates this research, which is to examine the implication of COE and COD on CSR performance disclosed through non-financial information in sus- 
tainability reporting of ASEAN top companies listed on 5 stock exchanges (Indonesia, Philippines, Malaysia, Thailand, and Singapore).

The next section of this research discusses the background literature that underlies the hypothesis development. In the third part, the research methodology used is explained. The fourth section will discuss the analysis and discussion of the results. The conclusion will be drawn in the last section, as well as research limitations and suggestions for future research.

\section{LITERATURE REVIEW AND HYPOTHESIS DEVELOPMENT \\ CSR in ASEAN}

ASEAN plays a critical role in the global economy. In addition, the use of mobile technology extensively and intensively has made it one of the fastest economic development regions. However, social, economic, and political problems still overshadow economic progress in ASEAN. The rapid economic development has made environmental scientists concern about Sustainable Development Goals (SDGs) achievement in ASEAN (Giri \& Anjanappa, 2017). In addition, sustainability disclosure is still voluntary for corporations. Thus, the disclosure of CSR performance in ASEAN is still limited to fulfilling obligations (Waworuntu, Wantah \& Rusmanto, 2014).

The increase in disclosure of CSR performance in ASEAN is mainly driven by the entry of Multinational Corporations (MNCs) in the region. MNCs that operate globally have policies that must meet regulations in various countries. These policies are applied to all subsidiaries, including those in ASEAN (Waworuntu et al., 2014).

\section{Stakeholder Theory}

Stakeholder theory has long been used to explain the linkage of a company's objectives with productivity and efficiency, social welfare, and accountability of managers and directors (Jensen, 2001). At its core, this theory has been used to explain what is the main purpose of a corporation. Donaldson \& Preston (1995) explained, that based on stakeholder theory, a corporation is an intersection of numerous and various interests. Those interests are not always congruent, let alone similar. Managers and directors should take-into account most, if not all, the interest of the stakeholders when decision-making for the sake of the company. These stakeholders consist of any parties who can impact or be affected by the decision made by managers, such as owners, government, suppliers, customers, employees, competitors communities, and other parties (Freeman, 2015). In this sense, the purpose of a corporation is not solely for value maximization, especially for shareholders or investors. A corporation must serve the interest of many stakeholders fairly (Jensen, 2001).

Based on that argument, stakeholder theory has been used to explain the CSR activities of companies. Ullman (1985) provides a framework to justify the correlation between CSR performance and disclosure. First, the company will be more likely to satisfy the interest of a stakeholder who has critical resources for the company or stakeholder power is positively related to CSR performance and disclosure. Second, the company that is actively engaged in CSR activities will have better CSR disclosure. Third, the company with better financial performance will have better CSR performance. Furthermore, Ullman's (1985) framework not only provides justification of CSR activities, but it also suggests evidence that strategic decision-making can be included in CSR activities.

\section{CSR and Information Asymmetry}

Various voluntary reporting standards have been developed to offer guidelines regarding relevant CSR information and practices that must be disclosed. This is because broader financial information will be able to decrease information asymmetry and offer a more comprehensive representation of company performance (Kusuma \& Aryani, 2020).

Research done by Cui, Jo \& Na (2018) shows an opposite relationship between CSR and the degree of information asymmetry in companies in the United States. High CSR performance can reduce information asymmetry. In addition, when studying the causal relationship between the 
two, Cui et al. (2018) discover that the outcome of CSR activities on information asymmetry is greater than the outcome of information asymmetry on CSR activities. The findings of these studies are following stakeholder theory. Based on stakeholder theory, companies exercise CSR as a means to better coordinate between managers and non-financial stakeholders.

In addition, earnings management can have negative, positive, or no effect on CSR performance. However, if a company with high CSR performance aims to increase financial transparency and has a good image, then the company must reduce earnings management practices. Conversely, if the company aims to meet various demands from stakeholders, then management must report good financial performance and profits must continue to increase to disguise less than expected results (Cheng, Ioannou \& Serafeim, 2014).

Cho, Lee \& Pfeiffer (2013) also identify that positive and negative CSR performance both reduces information asymmetry. But investors react more to negative CSR performance information than positive CSR performance. Furthermore, research conducted by Kim, Park \& Wier (2012) shows that companies with high CSR performance tend not to practice earnings management and not to manipulate their financial data. The company is more conservative in implementing its accounting system. Therefore, the possibility of these companies being audited by government agencies is lower because the information presented in the financial statements is considered more transparent.

\section{CSR and Cost of Equity (COE)}

Based on stakeholder theory, a company must consider the interest of many stakeholders. Managing stakeholders' demands fairly will give benefit to the company as it will secure the going concern of the company (Breuer, Müller, Rosenbach \& Salzmann, 2018). Besides, managers practice CSR to meet their ethical responsibilities regarding their stakeholders. Companies with positive ethical practices will have better access to the financial market (García-Sánchez et al., 2019). Ng \& Rezaee (2015) also argue that committing to superior CSR activities is a form of applying strategic activities by conducting social and environmental issues that matter the most for their stakeholders. By doing so, companies will gain a positive reputation as good corporate citizens.

Prior studies have shown that effective governance and more strict disclosure standards can decrease the cost of equity (COE) due to lower agency costs and information asymmetry. CSR performance influences the perceived risk of companies. Therefore, socially responsible companies can advantage from reduced costs of equity (El Ghoul, Guedhami, Kwok \& Mishra, 2011). In addition, better CSR performance can initiate better access to sources of capital. Access to better sources of capital is due to the involvement of stakeholders, reduction of agency costs, and reduction of information asymmetry due to the increase in reporting transparency (Cheng et al., 2014). Other research in China shows that superior CSR performance will decrease the cost of equity in the capital market $(\mathrm{Xu}$, Liu \& Huang, 2015). Based on these studies, the first hypothesis is:

H1: Companies with higher CSR performance have lower cost of equity.

\section{CSR and Cost of Debt}

Companies willing to disclose CSR performance are more associated with trust, integrity, and are not opportunistic. Based on stakeholder theory, higher companies' contribution to broader stakeholders will give support to create higher value and more positive image and finally will increase financial performance (Magnanelli \& Izzo, 2017). The companies' high involvement with the environment and community is the companies' commitment to working with various stakeholders on a foundation of trust. Therefore, companies with high CSR performance will have a good reputation so that they have better debts' covenant (Nguyen. Choi \& Agbola, 2020). Companies' strategy that takes into account and manages conflict of interests among their stakeholders well, also will lower liquidity and information asymmetry risks faced by creditors (Suto \& Takehara, 2017). Houqe, Ahmed \& Richardson (2020) also find that 
companies with good Environment, Social, and Governance (ESG) performance have a significant negative relationship with COD. Chava (2014) further gives evidence that banks give less loan to companies that engage in questionable environmental practices.

Research conducted by Cheng et al. (2014) show that companies with good CSR performance have higher access to capital. The ease of access to finance is caused by two factors. First, the agency cost is reduced because of the higher involvement with stakeholders. Second, information asymmetry is reduced due to increased information transparency. Research conducted by Cooper \& Uzun (2015) also finds that good CSR performance can reduce yield spreads and yield to maturity on debt. They argue that companies involved in social and environmental welfare will find it easier and cheaper to obtain resources and debt compared to companies that have lower CSR performance. Based on previous explanation, second hypothesis would be:

H2: Companies with higher CSR performance have lower cost of debt.

\section{RESEARCH METHODS}

This study was designed to explore the relationship between CSR disclosure and COC represented by COE and COD. The sample of this study was the top 40 companies listed on stock exchanges in Indonesia, Singapore, Malaysia, Thailand, and the Philippines. The sampling method used was purposive sampling with the following conditions. First, samples were included in the top 40 companies based on market capitalization on each country's stock exchange. Second, samples had complete financial data and sustainability reporting from 2017 to 2019. Determination of market capitalization and financial data for sample companies were obtained using the Osiris database and publicly available secondary data. The number of samples obtained was 200 companies with 3 years of observation. The determination of the relationship between CSR disclosure with COE and COD was tested by multiple regression analysis as shown in the following empirical models:

$$
\begin{aligned}
& \mathrm{COE}_{\mathrm{it}+1}=\beta_{0}+\beta_{1} \mathrm{CSR}_{\mathrm{it}}+\beta_{2} \mathrm{LEV}_{\mathrm{it}}+\beta_{3} \mathrm{CHER}_{\mathrm{it}}+ \\
& \beta_{4} \mathrm{MTB}_{\mathrm{it}}+\beta_{5} \mathrm{ROA}_{\mathrm{it}}+\beta_{6} \mathrm{OANCF}_{\mathrm{it}}+ \\
& \beta_{7} \text { SIZE }_{\text {it }}+\mathrm{e}_{\mathrm{it}} \ldots \ldots \ldots \ldots \ldots \ldots \ldots \ldots \ldots . .(1) \\
& \operatorname{COD}_{\mathrm{it}+1}=\beta_{0}+\beta_{1} \mathrm{CSR}_{\mathrm{it}}+\beta_{2} \mathrm{LEV}_{\mathrm{it}}+\beta_{3} \mathrm{CHER}_{\mathrm{it}}+ \\
& \beta_{4} \mathrm{MTB}_{\mathrm{it}}+\beta_{5} \mathrm{ROA}_{\mathrm{it}}+\beta_{6} \mathrm{OANCF}_{\mathrm{it}}+ \\
& \beta_{7} \text { SIZE }_{\text {it }}+\mathrm{e}_{\mathrm{it}} \ldots \ldots \ldots \ldots \ldots \ldots \ldots \ldots \ldots . .(2)
\end{aligned}
$$

The relationship of CSR disclosure on COE and COD can be observed from the coefficient of $\beta_{1}$. If the coefficient of $\beta_{1}$ was significant then CSR activities and disclosure would affect COE and COD paid by companies differently. Therefore, both research hypotheses could be supported.

CSR disclosure was the independent variable of this study. Measurement of CSR disclosure was based on the compliance of the companies' sustainability reporting with the Global Reporting Initiative (GRI) Standard. GRI Standard provides direction and reference for companies to disclose their CSR activities and provides a sustainability measure of CSR activities. Sustainability reporting is an organization's effort to measure, disclose, and be accountable to internal and external stakeholders regarding organizational performance to achieve Sustainable Development Goals (SDGs) (Waworuntu et al., 2014). GRI Standards consists of 36 items which are divided into universal standard, economic topics, environmental topics, and social topics.

Assessment of compliance with GRI Standard was carried out by analysing content or information in sustainability reporting or annual reports published by the company. This compliance was done by examining whether each item in the GRI Standard had been disclosed in the company's sustainability reporting. Therefore, the maximum value of this variable was 36 , which meant that the company had carried out and disclosed CSR activities under all of the GRI Standard guidelines.

The dependent variable of this study was the cost of capital (COC) which consisted of cost of debt (COD) and cost of equity (COE). COD was calculated as follows (Yeh et al., 2019).

$$
\mathrm{COD}=\frac{\text { Interest rate expense year } \mathrm{t}}{\text { Average debt year t..........(3) }}
$$

Whereas COE was measured as the 
excess of return received by investors as follows (Yeh et al., 2019).

$$
\mathrm{COE}=\mathrm{R}_{\mathrm{it}}-\mathrm{R}_{\mathrm{ft}}=\alpha+\beta\left(\mathrm{R}_{\mathrm{mt}}-\mathrm{R}_{\mathrm{ft}}\right) \ldots
$$

With: $\mathrm{R}_{\mathrm{it}}=$ individual stock return in year $\mathrm{t}$; $\mathrm{R}_{\mathrm{ft}}=$ risk-free rate in year $\mathrm{t}$; $\mathrm{R}_{\mathrm{mt}}=$ market return in year $\mathrm{t} ; \mathrm{R}_{\mathrm{it}}-\mathrm{R}_{\mathrm{ft}}=$ excess return on individual stocks; $\mathrm{R}_{\mathrm{mt}}-\mathrm{R}_{\mathrm{ft}}=$ market factor; $\beta=$ beta

In addition to the disclosure of CSR, other control variables that can affect COE and COD were also considered in this study. The control variables used were LEV, CHER, MTB, ROA, OANCF, and SIZE. LEV was companies' financial leverage. Leverage was the ratio between total debt and total assets. The higher the leverage the companies used, the higher the liquidity risk (Nguyen et al., 2020). Therefore, the higher the leverage will increase the companies' COE and COD (Bhuiyan \& Nguyen, 2019). CHER was the amount of cash companies held. It was measured as a ratio of cash to total assets. Investors and creditors prefer companies that have the optimal amount of cash. Therefore, the relationship between CHER with COE and COD was predicted to be negative (Yeh et al., 2019). MTB was market-to-book value measured by comparing stock market price with its book value (Kusuma \& Aryani, 2020). Low MTB indicates that the share price is priced lower. Therefore, companies that have low MTB will have high COC (Fama \& French, 1992). The next control variable was ROA which was a return on assets. ROA is a per- formance indicator that measures a company's profitability (Waworuntu et al., 2014). Therefore, high ROA can reduce COE and COD (Pontoh \& Ilat, 2013). OANCF was the ratio between operating net cash flow and total assets. This ratio showed the amount of net operating cash obtained from assets (Yeh et al., 2019). Therefore, high OANCF can reduce $\mathrm{COE}$ and COD. The last control variable was SIZE which was measured by the natural logarithm of total assets. Larger companies tend to get loans or debt and sell their shares easier. Larger firms also spend costs involved in obtaining a loan and selling the shares lower. This is related to expectations of the companies' financial performance in the future. Therefore, the larger the SIZE, the lower COE and COD (Nguyen et al., 2020).

\section{ANALYSIS AND DISCUSSION Descriptive Statistics}

Table 1 is the descriptive statistics of the samples obtained. The mean values of COE and COD were 3.108 and 0.072. Companies in ASEAN paid higher COE than COD. The average value of CSR disclosure in ASEAN was 24. This meant that companies in ASEAN disclosed, on average, 24 items out of 36 items stipulated by GRI Standard in their sustainability reporting. The average CHER and OANCF values were 0.103 and 0.092. The top companies in ASEAN had relatively less cash compared to other assets. In line with this, the average values of ROA and SIZE were 8.700 and 14.606. This meant that the top companies in ASEAN

Table 1.

Descriptive statistics of the samples

\begin{tabular}{lrrrrr}
\hline \multicolumn{1}{c}{ Variables } & N & Minimum & \multicolumn{1}{c}{ Maximum } & \multicolumn{1}{c}{ Mean } & Std. Deviation \\
\hline COE & 573 & 1.150 & 6.070 & 3.108 & 1.399 \\
COD & 573 & -0.010 & 1.670 & 0.072 & 0.130 \\
CSR & 573 & 0.000 & 36.000 & 24.400 & 11.129 \\
LEV & 573 & -1.840 & 7.260 & 0.683 & 0.794 \\
CHER & 573 & 0.000 & 0.600 & 0.103 & 0.093 \\
MTB & 573 & -0.180 & 72.620 & 3.406 & 6.278 \\
ROA & 573 & -47.960 & 65.260 & 8.700 & 9.432 \\
OANCF & 573 & -0.280 & 0.560 & 0.092 & 0.100 \\
SIZE & 573 & 10.970 & 18.100 & 14.606 & 1.428 \\
\hline \hline
\end{tabular}


had more fixed assets. The average MTB of 3,406 meant that the market value of most firms was higher than their book value.

Before conducting hypothesis analysis, the data obtained must meet several assumptions. None of the variables have a VIF value of more than 10 . Thus, there was no correlation between independent variables. In addition, the Durbin-Watson test value was 1.984 so there was no correlation between periods. The residue variance of each variable was also homogeneous due to the probability value of each variable from the heteroscedastic test resulted from more than 0.05 . The probability of the Kolmogorov-Smirnov test was 0.059 . Thus, the data were normally distributed.

\section{Correlation Analysis}

Table 2 shows the results of the Pearson correlation analysis. CSR and SIZE disclosures had a significant correlation with COE and COD. Therefore, based on Pearson correlation, CSR and SIZE can reduce COE and COD of companies. In addition, CHER and MTB also had a significant correlation with COE and COD. However, companies with high CHER and MTB had high COE and COD as well. LEV was also significantly correlated with COD. That is, companies with a high level of leverage had low COD. Furthermore, companies with high levels of leverage, OANCF, and SIZE disclosed more information about CSR. It was shown by a significant and positive correlation value. On the other hand, companies with high cash holdings disclosed less CSR.

\section{Hypothesis Analysis}

Based on the result of regression analysis, $\mathrm{R}^{2}$ value of the first model was 0.413 and the $F$ value was 16.617 ( $p<0.05$ ). Therefore, independent and control variables simultaneously affect COE in the first model. Based on regression analysis results, it can be seen that disclosure of CSR performance had a negative significant effect on $\mathrm{COE}$ (coefficient $=-0.014, \mathrm{p}<0.05)$. This result supported the first hypothesis. Regression analysis results of CSR disclosure and control variables on COD are shown in table 3 in the fourth and fifth columns. The $\mathrm{R}^{2}$ value of this second model was 0.310 and the F value was $8,576(\mathrm{p}<0.000)$. This means that independent and control variables simultaneously influence COD. In addition, COD can be explained by independent and control variables by 31 percent. Regression analysis results showed that better disclosure of CSR performance did not affect COD (coefficient $=0.000, \mathrm{p}>0.05$ ). Therefore, $\mathrm{H} 2$ was not supported.

Based on the regression analysis results, disclosing more CSR can reduce COE. This result was in line with researches conducted by Ahmed et al. (2019); Bhuiyan \& Nguyen (2019); Cuadrado-Ballesteros, Garcia-Sanchez \& Martinez Ferrero (2016); Cui et al. (2018); Michaels \& Grüning (2017); Pusparida \& Harto (2016); Suto \& Takehara (2017); Xu et al. (2015). Companies with better CSR performance have significantly lower COE. CSR, which plays an important role for investors, is primarily a better governance mechanism and ensures infor-

Table 2.

Pearson correlation of the variables

\begin{tabular}{|c|c|c|c|c|c|c|c|c|c|}
\hline & $\mathrm{COE}$ & COD & LEV & CHER & MTB & ROA & OANCF & SIZE & CSR \\
\hline $\mathrm{COE}$ & 1.000 & & & & & & & & \\
\hline COD & 0.070 & 1.000 & & & & & & & \\
\hline LEV & 0.014 & $-0.150^{\text {*wt }}$ & 1.000 & & & & & & \\
\hline CHER & $0.164^{* *}$ & 0.070 & $-0.184^{* * *}$ & 1.000 & & & & & \\
\hline МТВ & -0.062 & $0.091^{*}$ & $0.333^{* * *}$ & -0.021 & 1.000 & & & & \\
\hline ROA & 0.022 & 0.015 & $-0.118^{* * *}$ & $0.200^{* * *}$ & $0.490^{* * *}$ & 1.000 & & & \\
\hline OANCF & 0.023 & 0.055 & -0.026 & $0.226^{* *}$ & $0.462^{* *}$ & $0.735^{\text {*a }}$ & 1.000 & & \\
\hline SIZE & $-0.313^{* *}$ & $-0.245^{\ldots * w}$ & $0.252^{* * *}$ & $-0.203^{* *}$ & $-0.234^{* * *}$ & $-0.338^{\ldots * *}$ & $-0.283^{\text {** }}$ & 1.000 & \\
\hline CSR & $-0.196^{* * *}$ & $-0.093^{\prime \prime}$ & $0.129^{* * *}$ & $-0.195^{*}$ & 0.059 & 0.038 & $0.116^{* *}$ & $0.220^{* * *}$ & 1.000 \\
\hline
\end{tabular}


mation transparency. Shareholders will demand higher returns to companies with poor CSR performance (Xu et al., 2015). In addition, companies that have a broad impact on CSR activities can improve sustainable competitive advantage by decreasing undesirable effects of their business activities on the environment and society while also obtaining low COE costs (Ahmed et al., 2019). Summary of the regression analysis are showed in table 3 .

Its also shows that LEV had a significant positive effect on $\mathrm{COE}$, as predicted (coefficient $=0.377, \mathrm{p}<0.05$ ). The higher the leverage of the companies the higher the COE (Bhuiyan \& Nguyen, 2019; Cooper \& Uzun, 2015; Cuadrado-Ballesteros et al., 2016; Michaels \& Grüning, 2017; Xu et al., 2015). MTB and SIZE also had significant negative effect on COE (coefficient $=-0.049$ and $-0.361, \mathrm{p}<0.05$ ). Companies with higher shares value than their book value have lower COE (Bhuiyan \& Nguyen, 2019; Cuadrado-Ballesteros et al., 2016; Xu et al., 2015). Furthermore, larger companies also have lower COE (Bhuiyan \& Nguyen, 2019; Cooper \& Uzun, 2015; CuadradoBallesteros et al., 2016; Cui et al., 2018; Michaels \& Grüning, 2017; Xu et al., 2015). However, CHER had a significant positive effect on COE. This means that companies that have more cash have higher COE (coefficient $=1.482, \mathrm{p}<0.018$ ). Based on research conducted by Suto \& Takehara
(2017), companies' ability to generate longterm profitability is the main focus of investors. On the other hand, investors will have a perception that the companies are at high risk if they have high short-term liquidity.

Contrary to COE, CSR disclosure did not have a significant effect on COD. This result is following the research conducted by Hashim et al. (2019). They found that CSR carried out by telecommunications companies in ASEAN has no effect on company performance as measured by ROA. CSR costs incurred were only seen as the implementation of obligations that must be carried out by companies. As result, creditors did not consider CSR activities to have an impact on the environment or society. Hence, they did not affect COD. However, if the company did not perform CSR for some profit reasons, the company could be considered environmentally irresponsible (Hashim et al., 2019). Similar results were also obtained from research conducted by Suto \& Takehara (2017) which examined the relationship between CSR performance and COC in Japan. They argue that CSR performance did not provide additional information. As result, it did not affect COD. CSR activities were an expense that was not perceived as a reduction in corporate risk.

Similar to COE, ROA and SIZE had a significant negative effect on COD

Table 3.

Analysis results

\begin{tabular}{lrrrr}
\hline \multirow{2}{*}{ Variables } & \multicolumn{2}{c}{ COE } & \multicolumn{2}{c}{ COD } \\
\cline { 2 - 5 } & Coefficients & Probability & Coefficients & Probability \\
\hline CSR & $-0.014^{*}$ & $0.006^{*}$ & 0.000 & 0.446 \\
LEV & $0.377^{*}$ & $0.000^{*}$ & $-0.028^{*}$ & $0.000^{*}$ \\
CHER & $1.482^{*}$ & $0.018^{*}$ & 0.031 & 0.611 \\
MTB & $-0.049^{*}$ & $0.000^{*}$ & $0.004^{*}$ & $0.001^{*}$ \\
ROA & 0.001 & 0.905 & $-0.003^{*}$ & $0.001^{*}$ \\
OANCF & 0.151 & 0.855 & 0.086 & 0.285 \\
SIZE & $-0.361^{*}$ & $0.000^{*}$ & $-0.018^{*}$ & $0.000^{*}$ \\
Constant & $8.460^{*}$ & $0.000^{*}$ & $0.369^{*}$ & $0.000^{*}$ \\
R $^{2}$ & 0.413 & & 0.310 & \\
F-value & $16.617^{*}$ & $0.000^{*}$ & $8.576^{*}$ & $0.000^{*}$ \\
\hline
\end{tabular}

"statistically significant at 95\% 
(coefficient $=-0.003$ and $-0.018, \mathrm{p}<0.05$ ). This meant that larger companies with better financial performance had lower COD (Bhuiyan \& Nguyen, 2019; CuadradoBallesteros et al., 2016). On contrary, MTB had significant positive effect on COD (coefficient $=0.004, \mathrm{p}<0.05$ ). Companies with shares' market price higher than book value have higher COD.

\section{CONCLUSION}

The purpose of this study is to show the impact of CSR performance disclosure on COE and COD. The top 200 companies in ASEAN by market capitalization have been selected to test two predetermined hypotheses. The results of the regression analysis conducted to support the first hypothesis, better CSR performance disclosure will reduce COE. Based on stakeholder theory, fulfilling broader stakeholders' interests give a financial benefit to companies. Engaging in CSR activities and disclosures improves companies' long-term value and reputation through performing social and environmental obligations ( $\mathrm{Ng} \&$ Rezaee, 2015). Companies that have more nonfinancial disclosure are regarded to be more publicly accountable and have better corporate governance mechanisms. Those companies are perceived to have better earnings quality and reputation. Therefore, information asymmetry can be reduced and companies will be more attractive to institutional investors. The involvement of institutional investors and other stakeholders will be able to mitigate the companies' risk (Bhuiyan \& Nguyen, 2019).

Based on the second hypothesis analysis, it is found that CSR performance disclosure does not affect COD. Banks do not consider CSR as activities that create value or reduce risk (Magnanelli \& Izzo, 2017). In this circumstance, CSR is only considered as a tool to improve companies' reputation and ultimately to increase profit. CSR is not carried out to apply corporate ethical principles (Hashim et al., 2019). In addition, CSR activities are only limited to fulfilling the obligations required by regulations (Goss \& Roberts, 2011).

Corporations acquire benefits and profit from the community and natural en- vironment. As part of the community, corporations should play their part. What the corporations get, they should pay it forward in the form of CSR. With increasing awareness of corporations' impact on the environment, CSR is a must. The implementation of CSR may not affect the companies' financial performance, but not implementing it now has a bigger negative impact. Therefore, CSR must be implemented by every company.

This study gives several contributions, academically and practically. First, using stakeholder theory, this study gives additional empirical evidence to the linkage of CSR and COC literatures. Second, this study gives supporting evidence regarding financial benefits for companies practicing better CSR activities.

\section{LIMITATIONS AND SUGGESTIONS.}

This study has weaknesses due to the researcher's limitations. CSR variable in this research only measures the scope of CSR disclosure. This variable does not yet measure CSR performance level. CSR variable is assessed by a content analysis which is carried out only to measure whether CSR activities are under GRI Standard. The content analysis does not yet assess CSR performance level. Therefore, future research can use variables that measure CSR performance level.

\section{ACKNOWLEDGEMENT}

Authors wish to thank DRPM RISTEKBRIN for providing Research Grant.

\section{REFERENCES}

Ahmed, A.H., Eliwa, Y., \& Power, D.M. (2019). The impact of corporate social and environmental practices on the cost of equity capital: UK evidence. International Journal of Accounting \& Information Management, 27(3), 425-441.

Ainy, R.N., \& Barokah, Z. (2019). Corporate governance, environmental responsibility and firm value: An empirical study in Indonesia and Malaysia. Journal of Accounting and Investment, 20(2), 59-75.

Ali, I., Lodhia, S., \& Narayan, A.K. (2020). Value creation attempts via photographs in sustainability reporting: A 
legitimacy theory perspective. Meditari Accountancy Research, ahead-ofprint(ahead-of-print).

Anindita, G.N. (2014). Pengaruh program corporate social responsibility (CSR) terhadap kinerja keuangan pada bank di Kota Surakarta. Jurnal Akuntansi dan Bisnis, 14(2), Article 2.

Bhuiyan, Md. B.U., \& Nguyen, T.H.N. (2019). Impact of CSR on cost of debt and cost of capital: Australian evidence. Social Responsibility Journal, 16(3), 419-430.

Breuer, W., Müller, T., Rosenbach, D., \& Salzmann, A. (2018). Corporate social responsibility, investor protection, and cost of equity: A cross-country comparison. Journal of Banking \& Finance, 96, 34-55.

Chava, S. (2014). Environmental externalities and cost of capital. Management Science, 60(9), 2223-2247.

Cheng, B., Ioannou, I., \& Serafeim, G. (2014). Corporate social responsibility and access to finance. Strategic Management Journal, 35(1), 1-23.

Cho, S.Y., Lee, C., \& Pfeiffer Jr, R.J. (2013). Corporate social responsibility performance and information asymmetry. Journal of Accounting and Public Policy, 32(1), 71-83.

Cooper, E.W., \& Uzun, H. (2015). Corporate Social Responsibility and the Cost of Debt. Journal of Accounting \& Finance (2158-3625), 15(8).

Cuadrado-Ballesteros, B., Garcia-Sanchez, I.M., \& Martinez Ferrero, J. (2016). How are corporate disclosures related to the cost of capital? The fundamental role of information asymmetry. Management Decision, 54(7), 1669-1701.

Cui, J., Jo, H., \& Na, H. (2018). Does corporate social responsibility affect information asymmetry? Journal of Business Ethics, 148(3), 549-572.

De Villiers, C., \& Maroun, W. (2018). The future of sustainability accounting and integrated reporting. Sustainability Accounting and Integrated Reporting, Routledge, Abingdon, 163-170.

Donaldson, T., \& Preston, L.E. (1995). The stakeholder theory of the corporation: Concepts, evidence, and implications. Academy of Management Review, 20(1), 65-91.

El Ghoul, S., Guedhami, O., Kwok, C.C., \& Mishra, D.R. (2011). Does corporate social responsibility affect the cost of capital? Journal of Banking \& Finance, 35(9), 2388-2406.

Fama, E.F., \& French, K.R. (1992). The cross- section of expected stock returns. The Journal of Finance, 47(2), 427465.

Freeman, R.E. (2015). Stakeholder theory. Wiley Encyclopedia of Management, 1 -6 .

García-Sánchez, I.-M., Hussain, N., MartínezFerrero, J., \& Ruiz-Barbadillo, E. (2019). Impact of disclosure and assurance quality of corporate sustainability reports on access to finance. Corporate Social Responsibility and Environmental Management, 26(4), 832-848.

Giri, K., \& Anjanappa, J. (2017). Overview of sustainability initiatives by private sector in Asia Pacific with a focus on timber product (SSRN Scholarly Paper ID 2996150). Social Science Research Network.

Goss, A., \& Roberts, G.S. (2011). The impact of corporate social responsibility on the cost of bank loans. Journal of Banking \& Finance, 35(7), 1794-1810.

Haq, F.A. (2020). Pengaruh pengungkapan sustainability reports terhadap kinerja keuangan: JABE (Jurnal Akuntansi, Bisnis Dan Ekonomi), 7(1), 21-33.

Hashim, F., Ries, E.A., \& Huai, N.T. (2019). Corporate social responsibility and financial performance: The case of ASEAN Telecommunications Companies. FGIC 2nd Conference on Governance and Integrity 2019, 892-913.

Houqe, M.N., Ahmed, K., \& Richardson, G. (2020). The effect of environmental, social, and governance performance factors on firms' cost of debt: International evidence. The International Journal of Accounting, 2050014.

Jensen, M.C. (2001). Value maximization, stakeholder theory, and the corporate objective function. Journal of Applied Corporate Finance, 14(3), 821.

Kim, Y., Park, M.S., \& Wier, B. (2012). Is earnings quality associated with corporate social responsibility? The Accounting Review, 87(3), 761-796.

Kusuma, A.A., \& Aryani, Y.A. (2020). Corporate social responsibility dan kinerja perusahaan (Studi pada Perusahaan Manufaktur yang listing di BEI tahun 2016-2017). Jurnal Akuntansi dan Bisnis, 20(1), 91-102.

Loh, L., \& Thomas, T. (2018). Sustainability reporting in ASEAN Countries Indonesia, Malaysia, Philippines, Singapore, and Thailand. ASEAN CSR Network \& Centre for Governance, Institutions \& Organisations NUS Business School 
Singapore.

Magnanelli, B.S., \& Izzo, M.F. (2017). Corporate social performance and cost of debt: The relationship. Social Responsibility Journal, 3(2), 250-265.

Michaels, A., \& Grüning, M. (2017). Relationship of corporate social responsibility disclosure on information asymmetry and the cost of capital. Journal of Management Control, 28(3), 251274.

Ng, A.C., \& Rezaee, Z. (2015). Business sustainability performance and cost of equity capital. Journal of Corporate Finance, 34, 128-149.

Nguyen, V.H., Choi, B., \& Agbola, F.W. (2020). Corporate social responsibility and debt maturity: Australian evidence. Pacific-Basin Finance Journal, 62, 101374.

Oikonomou, I., Brooks, C., \& Pavelin, S. (2014). The effects of corporate social performance on the cost of corporate debt and credit ratings. Financial Review, 49(1), 49-75.

Pontoh, W., \& Ilat, V. (2013). Determinant capital structure and profitability impact (Study of listed company in Indonesian Stock Exchange). Research Journal of Finance and Accounting, 4(15), 43-49.

Pusparida, F.M., \& Harto, P. (2016). The effect of corporate sustainability disclosure on cost of capital in ASEAN banking sector: The moderating role of financial performance (Undergraduate Thesis) Universitas Diponegoro, Fakultas Ekonomika dan Bisnis, Semarang.

Safitri, N.F.W.F.W. (2013). Analisa pelaporan pengungkapan corporate social responsibility (CSR) berdasarkan pedoman Global Reporting Initiatives (GRI). Jurnal Akuntansi AKUNESA, 2 (1), Article 1.

Suto, M., \& Takehara, H. (2017). CSR and cost of capital: Evidence from Japan. Social Responsibility Journal, 13(4), 798-816.

Ullman, A. (1985). Data in search of a theory: A critical examination of the relationship among social disclosure and economic performance measures. Academy of Management Review, 19 (3), 30-39.

Waworuntu, S.R., Wantah, M.D., \& Rusmanto, T. (2014). CSR and financial performance analysis: Evidence from Top ASEAN listed companies. Procedia-Social and Behavioral Sciences, 164, 493-500.

Wimatsari, K.K. (2014). Pengaruh kinerja lingkungan terhadap corporate social responsibility (CSR Disclosure) dan kinerja finansial Perusahaan Manufaktur yang terdaftar di Bursa Efek Indonesia. Jurnal Akuntansi dan Bisnis, 14(1), Article 1.

Xu, S., Liu, D., \& Huang, J. (2015). Corporate social responsibility, the cost of equity capital and ownership structure: An analysis of Chinese listed firms. Australian Journal of Management, 40(2), 245-276.

Yeh, C.-C., Lin, F., Wang, T.-S., \& Wu, C.-M. (2019). Does corporate social responsibility affect cost of capital in China? Asia Pacific Management Review, 25(1), 1-12. 